\title{
КУЛЬТУРОВЕДЧЕСКИЙ АСПЕКТ В ПРАКТИКЕ ПРЕПОДАВАНИЯ РУССКОГО ЯЗЫКА КИТАЙСКИМ СТУДЕНТАМ
}

\section{CULTUROLOGICAL ASPECT IN THE \\ PRACTICE OF TEACHING RUSSIAN TO CHINESE STUDENTS}

\section{R. Teremova \\ V. Gavrilova Bai Yi}

Summary: The article considers the wide use of regional studies materials related to the cultural and historical space of St. Petersburg and the Leningrad region, aesthetic, artistic and historical components in the process of teaching Chinese students Russian. There is much attention paid to the description of the interactive and communicative learning mode, which conceptually defines the interaction of teacher and students, as well as the interaction of students and allows to introduce innovative pedagogical technologies into the educational process. The article substantiates the effectiveness of the introduction of the linguoculturological aspect in the practice of teaching Russian to Chinese students.

Keywords: linguoculturology, communicative and cultural concept, regional component, interactive organization of the learning process, cultural and historical space of St. Petersburg.
Л ингвокультурология как «отрасль лингвистики, возникшая на стыке лингвистики и культурологии и исследующая проявления культуры народа, которые отразились и закрепились в языке» [1, с.29], внесла новые, концептуально значимые коррективы в теорию и методику обучения РКИ. В связи с этим в последние десятилетия возросла роль культуроведческого компонента в обучении русскому языку иностранных учащихся.

Сложившаяся сегодня в методике преподавания русского языка как иностранного коммуникативно-культурологическая концепция своей стратегической целью имеет овладение иностранными учащимися русским языком на основе познания и усвоения фактов культуры, в процессе приобщения личности к русской культуре и ее участия в диалоге культур. При этом ведущей, доминирующей функцией обучения в этом случае является культурологическая, когда культура признается собственно содержанием образования.
Теремова Римма Михайловна

Д.филол.н., профессор, Российский государственный педагогический университет им. А.И. Герцена, заслуженный деятель науки РФ teremova_2003@mail.ru

Гаврилова Валентина Леонидовна

К.филол.н., Российский государственный педагогический университет им. А.И. Гериена gavrilova_spb@mail.ru

Бай $и$

старший преподаватель, Шанхайский университет иностранных языков baiyi8050@163.com

Аннотация: В статье рассматривается широкое использование в процессе обучения китайских студентов русскому языку регионоведческих материалов, связанных с культурно-историческим пространством Санкт-Петербурга, пригородов и Ленинградской области, его эстетически-художественной и исторической составляющих. Большое внимание уделяется описанию интерактивно-коммуникативного режима обучения, концептуально определяющего взаимодействие обучающего (преподавателя) с обучаемыми, а также взаимодействие обучаемых и позволяющего использовать в учебном процессе инновационные педагогические технологии. В статье обосновывается результативность внедрения лингвокультурологического аспекта в практику преподавания русского языка китайским студентам.

Ключевые слова: лингвокультурология, коммуникативно-культурологическая концепция, регионоведческий компонент, интерактивная организация процесса обучения, культурно-историческое пространство Санкт-Петербурга.

Одной из важных целей языкового образования в Китае сегодня признается воспитание личности нового типа - личности, способной к продуктивному общению с носителями других культур без утраты собственной культурной идентичности, но за счет ее обогащения и возможной трансформации.

В этой связи особенно значимой становится стажировка китайских студентов в российских университетах, где они получают целостное и адекватное представление о картине мира русского народа, его культуре.

Важнейшей составляющей процесса обучения китайских студентов русскому языку в аспекте диалога культур в условиях языковой среды является регионоведческий компонент, ознакомление обучаемых с культурно-исторической характеристикой региона России, где они обучаются, так как, познавая культуру, традиции, историю региона, они через регион познают культурные реалии страны в целом. 
Безусловно, актуально для китайских студентов, обучающихся в Санкт-Петербурге, постижение культурноисторического пространства Санкт-Петербурга, «культурной столицы» России: оно позволяет им погрузиться в мир культуры носителей русского языка, лучше понять ценностные установки и социальные нормы русского народа и в результате подготовиться к адекватному участию в коммуникативно-познавательной деятельности в новом для них социуме.

Содержательное наполнение процесса обучения китайских студентов в целом можно свести к двум взаимосвязанным составляющим: эстетически-художественному (характеристика объектов культуры: архитектурные ансамбли, дворцы, храмы, музеи, монументальная скульптура, живопись и др.) и историческому (историческое осмысление культуры Санкт-Петербурга, его пригородов и Ленинградской области).

Культурное пространство Санкт-Петербурга включает в себя богатейший материал: архитектурные ансамбли, чаще всего с объектами монументальной скульптуры: Дворцовая площадь, ансамбль которой (Зимний дворец, Главный штаб, Триумфальная арка, Александровская колонна, Штаб гвардейского корпуса) создавался разными архитекторами, скульпторами и художниками в разное время и в разных стилях; Сенатская площадь (здания Сената и Синода, памятник Петру l; ансамбль Исаакиевской площади (Исаакиевский собор, Мариинский дворец, конный памятник Николаю I; площадь Искусств (Государственный Русский музей, Михайловский театр, Большой зал филармонии имени Д.Д. Шостаковича, Российский этнографический музей, Санкт-Петербургский государственный академический драматический театр имени В.Ф. Комиссаржевской, памятник А.С. Пушкину); Михайловский (Инженерный) замок, Невский проспект, Адмиралтейство, Васильевский остров с его многочисленными объектами культуры, музеи, природный и культурно-географический ландшафт (реки, каналы, мосты, парки, белые ночи и т.д.).

Представляется необходимым ознакомить китайских студентов с основными направлениями в различных сферах культуры, ролью известных архитекторов, скульпторов и художников в создании культурных объектов в Санкт-Петербурге (Доменико Трезини, Джакомо Кваренги, Карл Росси, Огюст Монферран, Франческо Бартоломео Растрелли, Этьен Фальконе и др.).

Постижение китайскими студентами основных направлений в разных сферах культуры города на Неве, культурной жизни, истории города будет наиболее эффективным при условии реализации обширной «культурной программы», а также при организации специальных учебных экскурсий (реальных и виртуальных) по местам Санкт-Петербурга, проводимых преподавателем или студентами, с последующим использованием полученных знаний на занятиях по русскому языку и лингвокультурологии.

Наибольшей оптимизации учебного процесса способствует проведение таких экскурсий, как «Рождение Санкт-Петербурга (Петропавловская крепость: Троицкая площадь, Иоанновский мост, Петровские ворота, Петропавловский собор, памятник Петру I, Комендантский дом, Ботный домик, Монетный двор, бастионы Петропавловской крепости, Невские ворота, пристань, Нева)», «Васильевский остров: архитектурные ансамбли Стрелки Васильевского острова, Университетская набережная (Зоологический музей, Кунсткамера, Российская академия наук, Санкт-Петербургский гос. университет, Меншиковский дворец)», «Площадь Искусств», «Невский проспект» («Нет ничего лучше Невского проспекта...»).

Всегда интересны для китайских студентов задания творческого характера по самостоятельному составлению экскурсионного материала. Например: Составьте экскурсионный маршрут, связанный с личностью рождения Петра I, поэтому она и будет называться так: «С днем рождения, Петр Алексеевич!»

Актуальным представляется ознакомление китайских студентов с культурно-исторической характеристикой региона, локализующегося вокруг Санкт-Петербурга, - пригородов и Ленинградской области (Пушкин, Павловск, Стрельна, Петергоф, Гатчина, Ломоносов), их возникновением и развитием, основными достопримечательностями, а также с миром русского искусства, деятельностью и бытом замечательных людей прошлого: художника и педагога П.П. Чистякова («Дом-музей П. Чистякова» в Пушкине), первого директора Императорской публичной библиотеки, президента Императорской Академии художеств А.Н. Оленина («Музей-усадьба А.Н. Оленина» в Приютино), великого русского художника И.Е. Репина (Музей-усадьба И.Е. Репина «Пенаты»), с литературно-художественными музеями («Дом станционного смотрителя» в Выре - музей литературного героя и дорожного быта, «Дом-музей няни А.С. Пушкина Арины Родионовны» в селе Кобрино).

Следуя принципу обучения в русле диалога культур, особое внимание следует уделять сопоставительному аспекту, ориентируя обучаемых на сравнение артефактов в Санкт-Петербурге и крупных городах Китая (Пекин, Шанхай и др.); полезным представляется и осмысление динамики их развития в обеих странах.

Например, на экскурсии «Санкт-Петербург и Шанхай - города-побратимы» студенты узнают, что два города, разделяемые 10 тысячами километров, являются городами-побратимами с 1988 года. На первый взгляд, трудно найти что-то общее между этими городами, однако 
их многое связывает. Например, Шанхай называют «головой Дракона» (т.е. Китая) из-за расположения города в устье реки Янцзы [2]. Иероглифы, которыми записывается название Шанхая, предполагают буквальное значение: «вступать на море», то есть выходить в море [3]. Возникает ассоциация с пушкинским «окном в Европу», которое прорубил Петр I, чтобы «ногою твёрдой встать при море». Оба города построены на болоте. Петербург раскинулся на берегах Невы, Шанхай - на берегах Янцзы. Оба города носят статус неофициальных столиц: Петербург - северной и культурной столицы, Шанхай - финансовой и промышленной. Оба города имеют поэтические названия: Петербург - «Северная Пальмира», «Северная Венеция», «Третий Рим», Шанхай - «Восточный Париж», «Королева Востока», «Жемчужина Востока».

Живой интерес у китайских студентов вызывает знакомство с китайскими штрихами в культуре СанктПетербурга, а также его пригородов.

Весной 2003 года в честь 300-летия Санкт-Петербурга Шанхай подарил Санкт-Петербургу «Сад дружбы», точную копию шанхайского Сада Юйюань («Сада Радости» или «Сада Неторопливого Отдыха»).

Продолжением экскурсионной прогулки по Саду дружбы может стать знакомство обучающихся с первым памятником А.С. Пушкину в Санкт-Петербурге, установленным на Пушкинской улице в 1884 году. Продолжая «шанхайские параллели» экскурсии, полезно напомнить китайским студентам, что в Шанхае находится единственный памятник иностранному поэту в Китае: монумент был открыт к столетию со дня смерти А.С. Пушкина, снесен во время Культурной революции, а затем восстановлен в 1987 году. Экскурсию можно закончить чтением стихов А.С. Пушкина у памятника поэту.

Для разработки индивидуальных маршрутов по «китайскому Петербургу» целесообразно предложить студентам побывать в Институте Конфуция (один из филиалов - СПбГУ, Восточный факультет), в Центре восточных культур (библиотека В.В. Маяковского), в Центре китайской культуры (РГПУ им. А.И. Герцена), в книжном магазине «Жёлтый двор» по адресу переулок Ковенский, дом 14, в Российско-китайском бизнес-парке, открытом весной 2016 года в «Ленэкспо». Здесь можно познакомиться с литературой и традициями Востока, посетить лекции, мастер-классы, посмотреть кинофильмы, поучаствовать в работе языковых клубов.

При Екатерине II в Александровском парке Царского Села для приезжавших ко двору знатных гостей и придворных строится китайская деревня, насчитывающая около двух десятков построек. Деревня окружена тремя мостами. Особого внимания заслуживает Большой китайский мост: его парапет украшают высокие вазы, ветви кораллов и четыре фигуры китайцев.

В Верхнем парке Ораниенбаума Екатерина II распорядилась построить Китайский дворец в стиле рококо с интерьерами в восточном стиле (паркеты дворца уникальны по исполнению и количеству используемых пород дерева; на знаменитых паркетах дворца были выложены китайские иероглифы).

В Петергофе возле дворца «Монплезир» находится Китайский садик, спроектированный в XIX веке.

Подобные экскурсии стимулируют активную деятельность китайских студентов, направленную на познание культуры Санкт-Петербурга в сопоставительном аспекте, и, несомненно, «являются одной из наиболее эффективных форм введения регионоведческих материалов в процесс обучения иностранных учащихся русскому языку» [4, с.119].

Задания и упражнения, предлагаемые студентам, также должны быть ориентированы на сопоставительный аспект, что приводит к более глубокому пониманию особенностей стиля жизни, ценностных установок, социальных норм поведения носителей русского языка [5, с.119].

По мере приобретения культуроведческих знаний китайские студенты начинают обнаруживать элементы общности и различия культур; при этом постижение новой для них культуры обогащает также их знание и понимание культуры своей страны и, что немаловажно, способствует формированию у них взгляда на мир как на глобальное пространство, включающее множество взаимодействующих культур, позволяет сформировать бикультурные языковые личности, готовые к активному и полноценному сотрудничеству в современном поликультурном мире.

Безусловно, нельзя представить культурное пространство Санкт-Петербурга без осмысления его в исторической перспективе, историческом контексте. Это, в первую очередь, мотивировано тем, что конкретная историческая реальность порождает определенные культурные реалии. Меняются исторические эпохи, а вместе с этим художественные течения, направления. Прежде всего, следует обратить внимание студентов на историю создания и развития Санкт-Петербурга, на роль личности Петра I в этом процессе и на культурные объекты, созданные в эпоху Петра I (Петропавловская крепость, Адмиралтейство, Летний сад, Летний дворец, Марсово поле). Необходимо показать общую картину становления города: сначала Петропавловская крепость, затем Васильевский остров и уже позже Адмиралтейский район, нынешний центр Санкт-Петербурга, выяснив причины именно такой последовательности его развития. 
При характеристике культурного пространства Санкт-Петербурга важно познакомить китайских студентов с историческими фактами, которые отразились на процессе становления города (Северная война со шведами 1700-1721гг., Отечественная война 1812 года), охарактеризовать исторических деятелей, а также деятелей русской культуры и науки (М.В. Ломоносов, И.И. Бецкой, А.В. Суворов, М.И. Кутузов, М.Б. Барклай-де-Толли и др.), привести исторические комментарии, в которых раскрываются факты, связанные с Северной войной и с Отечественной войной 1812 года, правлением не только Петра I, но и последующих императриц и императоров, представить культурные факты на фоне этапов истории и деятельности исторических личностей (например, Казанский собор, памятники М.И. Кутузову, М.Б. Барклаюде-Толли перед Казанским собором и информация об Отечественной войне 1812 года).

Большое внимание следует уделить методической организации учебного процесса, строящегося на коммуникативно-интерактивной основе, когда в качестве одного из главных требований к учебному процессу рассматривается принцип интерактивности, позволяющий определить учебный процесс как целостную структуру, коммуникативно-интерактивная организация которой концептуально определяется взаимодействием обучающего (преподавателя) с обучаемыми, а также взаимодействием обучаемых. Интерактивная активность качественно меняет характер взаимодействия преподавателя с учащимися. Возникает потребность в групповых обсуждениях, диалоге как норме межличностного взаимодействия, в котором все участники равны.

Коммуникативно-интерактивное обучение позволяет внедрить в учебный процесс разнообразный методический инструментарий, с преобладанием творческих проблемных заданий интерактивного характера, инновационные педагогические технологии: диалоги, полилоги, разнообразные ролевые игры, дискуссии («Москва и Санкт-Петербург - в зеркале истории и культуры России», «Петр І. Каким я его себе представляю?»), круглые столы («Петровский Петербург»), социологические опросы («Чем отличается Петербург от Москвы?»), клубы, телепередачи («История культуры Петербурга в XIX веке»), конкурсы («Мой Петербург»), праздники («Праздник мостов»), игры-квесты, в которых нужно «дойти до цели, последовательно решая творческие и интеллектуальные задачи» [6, с. 305] (например, «Проведите квест-экскурсию: найдите памятник Петру I, о котором не упоминается в тексте. Расскажите, где он установлен, опишите его»; «Найдите изображение герба СанктПетербурга петровского времени на одном из мостов. Итак, начали поиск...»).

В наибольшей степени приближают обучаемых к ситуации реального общения ролевые игры. При ролевой игре студенты принимают на себя те или иные социокультурные роли и проигрывают близкие к реальности ситуации общения.

Задания должны носить творческий, активизирующий характер, приглашать учащихся к рассуждению, к решению проблемных ситуаций. Так, например, для характеристики Петра I, а также такой неоднозначной личности, как Павел I можно использовать круглые столы («Петр I в истории России», «Павел I и его правление»). При проведении круглых столов студенты принимают активное участие в обсуждении проблемы, дают свою оценку личности и его деятельности.

Таким образом, педагогические интерактивные технологии - это, в первую очередь, разного рода игровые задания дискуссионного типа, когда китайские студенты должны понять проблему, высказать свою точку зрения, в конечном итоге в процессе позитивного, конструктивного диалога (полилога) прийти к позитивному решению значимых для всех коммуникантов проблем.

Особое значение имеет метод проектов, в частности такая его форма, как презентация на учебных занятиях выбранных студентами проблем по изучаемой теме, когда студенты, выступая в роли преподавателя, самостоятельно организовывают дискуссии.

Ярко выраженным интерактивным потенциалом обладают обучающие мастер-классы на самые различные темы.

Целесообразно использовать также культурологические тексты интерактивного характера во всем их многообразии, прежде всего, тексты экскурсий, как виртуальных, так и реальных, которые могут проводиться преподавателем или студентами. Чтобы экскурсия действительно была интерактивной (студенты должны задавать экскурсоводу вопросы, дополнять его рассказ информацией, делиться своими впечатлениями об увиденном), ей должна предшествовать значительная подготовительная работа. Студентам необходимо предложить таблицу с репликами экскурсовода и экскурсантов в процессе проведения экскурсии [7,с. 193].

Интересными представляются задания, сориентированные на организацию студентами экскурсий по заданному маршруту, а также на составление экскурсионных маршрутов самими студентами с последующим их проведением. Это могут быть экскурсии по СанктПетербургу (по Летнему саду, Летнему дворцу Петра I, Дворцовой площади, Сенатской площади и др.), а также виртуальные экскурсии по известным местам родных городов студентов, с использованием Интернет-материалов, туристических сайтов или специальных путеводителей на русском языке [8]. 


\begin{tabular}{|c|c|c|c|c|}
\hline \multicolumn{2}{|c|}{ Говорит экскурсовод } & \multicolumn{3}{|c|}{ Спрашивает экскурсант } \\
\hline 焉 & 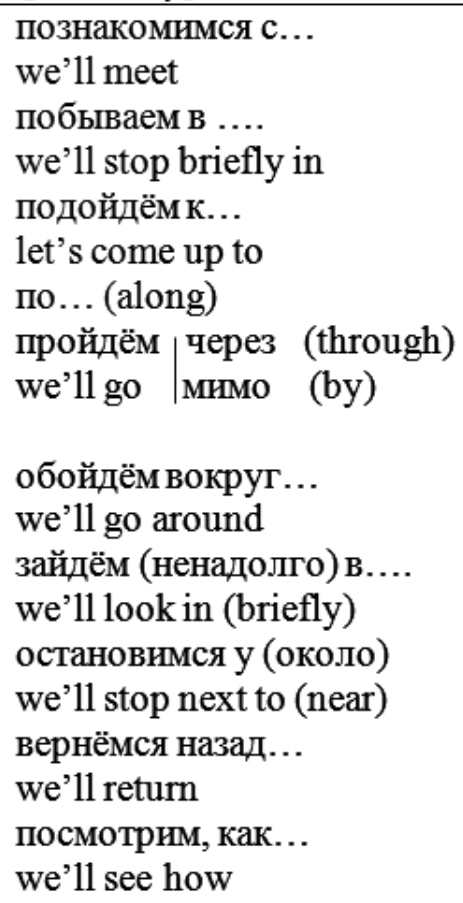 & 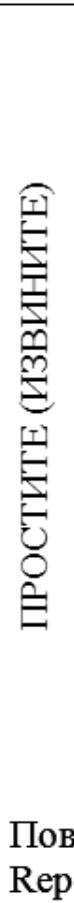 & $\begin{array}{l}\text { я хотел бы узнать } \\
\text { I would like to know } \\
\text { не могли бы вы } \\
\text { сказать } \\
\text { could you please tell me } \\
\text { я не понял } \\
\text { I didn't understand } \\
\text { я не paccлышал } \\
\text { I didn'thear } \\
\\
\text { не могли бы вы } \\
\text { повторить } \\
\text { соuld уоu please repeat } \\
\text { сорите, пожалуйста, скол } \\
\text { at please how many/muct }\end{array}$ & $\begin{array}{l}\text { где... } \\
\text { where... } \\
\text { что... } \\
\text { what... } \\
\text { когда... } \\
\text { when... } \\
\text { как... } \\
\text { how... } \\
\text { какой... } \\
\text { what kind } \\
\text { of... } \\
\text { ько }\end{array}$ \\
\hline $\begin{array}{l}\text { Обратите } \\
\text { внимание } \\
\text { Pay attention }\end{array}$ & $\begin{array}{l}\left.\begin{array}{l}\text { на...(to) } \\
\text { что... } \\
\text { на то, как.... } \\
\text { где... }\end{array}\right\} \begin{array}{l}\text { (that) } \\
\text { (tohow) } \\
\text { (where) }\end{array}\end{array}$ & & & \\
\hline $\begin{array}{l}\text { Посмотрите } \\
\text { Look }\end{array}$ & \begin{tabular}{l|l} 
направо & to the right \\
налево & to the left \\
вверх & up \\
вниз & down
\end{tabular} & & & \\
\hline
\end{tabular}

Интерактивный характер предлагаемых студентам текстов, в том числе текстов экскурсий, формируется использованием в них несобственно-прямой речи, когда автор (говорящий) представлен в двух ролях: и как лицо говорящее, и как лицо, воспринимающее чужую речь [9, с.231]: «Первым помощником и любимцем Петра I был кто? Правильно, Александр Данилович Меншиков»; «Вы обратили внимание на фонари, украшающие мост? Нет?! Тогда оглянитесь и полюбуйтесь ими...».

Эффективны задания оценочного характера: студенты должны высказать свое мнение (что им нравится/не нравится, почему), задания, ориентированные на впечатления студентов (они рассказывают о любимых местах в Санкт-Петербурге, о том, что дал им Петербург, чему их научил, что нового им открылось за время пребывания в Санкт-Петербурге, как повлиял на их мировоззрение, отношение к России, к русским, русскому языку), задания контролирующего характера, например, когда речь идет о названиях города: «Сколько имен у Петербурга?», «О Петербурге - одной строкой» и др.

Студентам предлагаются и творческие задания типа экспресс-интервью, например, взять «интервью» у других иностранных студентов, у знакомых, у петербуржцев (за что они любят Санкт-Петербург, от чего зависит их самочувствие, что надо сделать, чтобы город стал еще лучше). Такие задания требуют серьезной активизации внутренних ресурсов китайских студентов, с опорой на жизненный опыт, воображение, внимание, понимание окружающих.

Оптимизации учебного процесса способствует ознакомление китайских учащихся с соответствующей лексикой, с примерами их словосочетаний (памятник, монумент, площадь, дворец, храм, театр, колонна, фонари, кораблик, решетка). 


\begin{tabular}{|c|c|}
\hline \multicolumn{2}{|c|}{ ФОНАРИ } \\
\hline \multicolumn{2}{|c|}{ (какие?) красивые, разнообразные, лёгкие, особенные } \\
\hline украшают (что?) & $\begin{array}{l}\text { город } \\
\text { проспект } \\
\text { мост } \\
\text { набережную }\end{array}$ \\
\hline $\begin{array}{l}\text { придают своеобразие (чему? } \\
\text { не повторяют друг друга }\end{array}$ & \\
\hline
\end{tabular}

Познавая культуру Санкт-Петербурга, китайские студенты расширяют свои представления о России, ее культуре, что обогащает также и их знание культуры своей страны, адаптируются к новой для них образовательной и социокультурной среде, приобретает навыки свободного общения с носителями русского языка в условиях

\section{PEШЁTKA}

\begin{tabular}{|c|c|c|c|}
\hline \multirow[t]{4}{*}{ Решётка } & \multicolumn{3}{|c|}{$\begin{array}{l}\text { (какая?) полукруглая, изящная, с изящным рисунком, кру- } \\
\text { жевная, лёгкая, кованая, металлическая }\end{array}$} \\
\hline & выполнена по проекту & (кого?) & Воронихина \\
\hline & украшает & (4то?) & город \\
\hline & дополняет ансамбль & (чего?) & площади \\
\hline
\end{tabular}

русской языковой среды, приобщаются к картине мировидения, ценностным ориентирам русского народа, в результате чего уменьшается межкультурная дистанция между представителями русского и китайского народов, достигается взаимопонимание, воспитывается этническая толерантность.

\section{ЛИТЕРАТУРА}

1. Маслова В.А. Лингвокультурология: Учеб. пособие для студ. высш. учеб. заведений. - М.: Академия, 2001. - 208 с.

2. Мегаэнциклопедия Кирилла и Мефодия [Электронный ресурс]. - Режим доступа: https://megabook.ru/article/Шанхай свободный - (07.06.2020).

3. Википедия. Шанхай [Электронный ресурс]. - Режим доступа: https://dic.academic.ru/dic.nsf/ruwiki/9150 свободный - (07.06.2020).

4. Теремова Р.М. Роль регионоведческого компонента в успешной межкультурной коммуникации иностранных учащихся // Язык, культура, менталитет: проблемы изучения в иностранной аудитории: Материалы VI Международной научно-практической конференции 11-13 апреля 2007 г. - СанктПетербург: Изд-во РГПУ им. А. И. Герцена, 2007. - С.119-120.

5. Теремова Р.М., Гаврилова В.Л. Такие разные праздники. Лингвокультурологический аспект в обучении иностранных учащихся русскому языку // Русский язык за рубежом. - 2015. - №1 (248). - C.4-25.

6. Артамонова В.В., Гаврилова В.Л. Интерактивно-коммуникативный потенциал игровой деятельности при обучении иностранных студентов русскому языку // Современные тенденции в изучении и преподавании русского языка и литературы: Материалы докладов и сообщений XXII международной научно-методической конференции 03 февраля 2017 г. - Санкт-Петербург: Изд-во СПбГУПТД, 2017. - С. 302-306.

7. Теремова Р.М., Гаврилова В.Л. Окно в мир русской речи. Учебное пособие по русскому языку для иностранцев. - Санкт-Петербург: Изд-во Борей, 2001. 471 c.

8. Бай И. Познакомьтесь с достопримечательностями Шанхая, Сучжоу и Ханчжоу. Шанхай, Изд-во И Вэнь, 2007. — 246 с.

9. Лингвокультурология в теории и методике обучения русскому языку как иностранному: коллективная монография / Р.М. Теремова, В.Л. Гаврилова, 0.А. Игошина [и др.]; под общей редакцией Р.М. Теремовой. — Санкт-Петербург: Изд-во РГПУ им. А.И. Герцена, 2019. — 255 с.

\footnotetext{
(c) Теремова Римма Михайловна (teremova_2003@mail.ru), Гаврилова Валентина Леонидовна (gavrilova_spb@mail.ru), Бай И (baiyi8050@163.com).

Журнал «Современная наука: актуальные проблемы теории и практики»
} 